\title{
Influence of Frost Protection Windmachine with Continuous Oscillation on Microclimate in Tea Fields
}

\author{
Keda Sun ${ }^{1}$, Yongguang $\mathrm{Hu}^{1}$, Zhiyuan $\mathrm{Hu}^{1}$, Yongkang $\mathrm{Chen}^{1} \&$ Wuzhe Wei ${ }^{1}$ \\ ${ }^{1}$ School of Agricultural Equipment Engineering, Jiangsu University, Zhenjiang, Jiangsu, China \\ Correspondence: Yongguang Hu, School of Agricultural Equipment Engineering, Jiangsu University, Zhenjiang, \\ Jiangsu, China. E-mail: deerhu@163.com
}

Received: May 1, 2020 Accepted: May 17, 2020 Online Published: May 22, 2020

\begin{abstract}
To verify the influence of frost protection windmachine with continuous oscillation on microclimate, the experimental study was conducted in a tea field in Zhenjiang, China on a typical radiation frost night. Disturbed airflow variation and protection effect were investigated. Airflow velocity of 8 points at different distance from the machine was measured during an oscillation period with an anemometer, and temperature variation of 48 points at different distance from the machine and different height above the ground was measured with temperature recorders. The changes of airflow velocity and temperature were analyzed. Where the velocity was high, the airflow-disturbed duration was as well as large. Airflow velocity at each point presented a trend of rise, fluctuation, and decline under the action of windmachine with continuous oscillation. The temperature rise with the same distance from the machine was close, among which the $10 \mathrm{~m}$ and $20 \mathrm{~m}$ away from the machine increased greatly. Disturbed airflow enlarged the temperature difference between the top and the bottom of the canopy. The windmachine with continuous oscillation is proved to be effective for tea frost protection and provides more coverage than traditional anti-frost fan with flabellate oscillation.
\end{abstract}

Keywords: tea trees, windmachine, frost protection, disturbed airflow, temperature rise

\section{Introduction}

Frost is a common agro-meteorological disaster, which brings great harm to the growth of tea trees and other crops (Cittadini, et al., 2006; Gu, et al., 2008; Lu, et al., 2015). As mechanized equipment, frost protection windmachines have the advantages of larger coverage, better protective effect, and less pollution to environment than traditional methods such as smudging, flooding irrigation, and straw covering (Vahid, et al., 2015). The working principle of frost protection wind machine is to transport the airflow of the thermal inversion layer to the canopy of crops, and to drive off the cooler air at the same time (Battany, 2012; Doesken, et al., 1989). The frost protection wind machine can also improve the heat exchange between the crop and the surrounding air by regulating the conductivity of leaf boundary layer (Kensuke, et al., 2017; Monteith, et al., 2013; Snyder, et al., 2005). Many studies have confirmed that frost protection windmachine could effectively raise the temperature of the canopy (Bey-Marshall, et al., 2019; Heusinkveld, et al., 2019; Wu, et al., 2015), and could as well as increase the yield and quality of crops in the covered area (Blank, et al., 1995; Hu, et al., 2013). These studies mostly confirm the reliability of frost protection by comparing the conditions inside and outside the covered area.

Large frost protection windmachines, such as Model 3000 series windmachines (Orchard-Rite, Washington, USA) and Chinook windmachines (H.F.Hauff, Washington, USA), have achieved continuous oscillation, which improves the working efficiency (Gambino, et al., 2007; Lee, et al., 2013). The anti-frost fan is a kind of miniature windmachine which is suitable for some small and medium tea gardens in Japan (Kensuke, et al., 2017). Anti-frost fan oscillates with the angle of $60^{\circ}, 90^{\circ}$, or $120^{\circ}$, which has coverage less than $2000 \mathrm{~m}^{2}$. We applied mechanism of continuous oscillation to this kind of machine, to expand the covered area. However, in this case, the windmachine cannot continue to disturb airflow in the same direction, and the airflow with higher temperature in the thermal inversion layer is transmitted dispersedly. Therefore, the influence of frost protection windmachine with continuous oscillation on microclimate should be further confirmed. In addition, the discrepancy of the influence at different positions and heights in covered area should also be explained in detail. Airflow velocity and temperature rise are important indicators to measure the function of frost protection windmachine. In this study, the windmachine with continuous oscillation was started on a typical radiation frost night in a tea field. It is of much importance to know the airflow distribution and temperature rise when the windmachine with continuous 
oscillation is in operation in order to obtain better frost protection effect.

\section{Materials and Methods}

\subsection{Experimental Site}

Experimental tea field is located at Sanquan modern agricultural park in Zhenjiang, China $\left(32^{\circ} 05^{\prime} 33^{\prime \prime} \mathrm{N}\right.$, $119^{\circ} 22^{\prime} 12^{\prime \prime}$ E). It is a typical hilly tea field in the middle and lower of Yangtze River region. It has a temperate climate, and radiation frost happens frequently in the winter and spring seasons. Sampled tea variety is Anji white tea, which was five years old and the height was about $85 \mathrm{~cm}$. Frost protection experiment was conducted on a typical radiation frost night from December 4, 2019 to December 5, 2019.

\subsection{Experimental Materials}

In the center of the field, a windmachine with continuous oscillation (Fengke, Jiangsu, China) was installed for tea frost protection. Circular-arc blade was used on the windmachine. Its specifications are shown in Table 1. In addition, the materials also include: temperature and humidity automatic recorder ZDR-3W1S (Hangzhou Zeda, China), which has $\pm 0.1^{\circ} \mathrm{C}$ accuracy and measurement range of $-50 \sim 100^{\circ} \mathrm{C}$; anemometer AVM-07 (Taishi, China), which has $\pm 0.3 \mathrm{~m} \mathrm{~s}^{-1}$ accuracy and measurement range of $0 \sim 45 \mathrm{~m} \mathrm{~s}^{-1}$; poles, steel tape and stopwatch.

Table 1. Specifications of frost protection windmachine

\begin{tabular}{ccccc}
\hline $\begin{array}{c}\text { Power } \\
(\mathrm{kW})\end{array}$ & $\begin{array}{c}\text { Installed angle } \\
\left({ }^{\circ}\right)\end{array}$ & $\begin{array}{c}\text { Installed height } \\
(\mathrm{m})\end{array}$ & $\begin{array}{c}\text { Oscillation angle } \\
\left({ }^{\circ}\right)\end{array}$ & $\begin{array}{c}\text { Oscillation period } \\
(\mathrm{s})\end{array}$ \\
\hline 4.0 & $30^{\circ}$ & 9.0 & 360 & 190 \\
\hline
\end{tabular}

\subsection{Experimental Design}

Three experiments were conducted as following:

Frost protection group: The measurement points of airflow were set every $5 \mathrm{~m}$ within the distance of $40 \mathrm{~m}$ from the machine in certain direction, and the height of measurement points from the ground was $85 \mathrm{~cm}$. When the natural wind speed was low, the variation of airflow velocity was recorded by the anemometer during an oscillation period, and 8 groups of airflow velocity were measured. Vertical poles with a height of $1.0 \mathrm{~m}$ were erected in the direction of the east (group 1), west (group 2), north (group 3), and south (group 4) of the machine and at distances of $10 \mathrm{~m}, 20 \mathrm{~m}, 30 \mathrm{~m}$, and $40 \mathrm{~m}$ from the machine. The measurement points of temperature were set at $5 \mathrm{~cm}$ (bottom of canopy), $45 \mathrm{~cm}$ (middle of canopy), and $85 \mathrm{~cm}$ (top of canopy) high above the ground. A temperature sensor probe was placed at each point. Totally 48 groups of temperature were tested.

Control group: A vertical pole with a height of $1.0 \mathrm{~m}$ was erected at a distance of $100 \mathrm{~m}$ from the machine, and measurement points of temperature were set at the heights of $5 \mathrm{~cm}, 45 \mathrm{~cm}$, and $85 \mathrm{~cm}$ from the ground respectively.

Measurement of thermal inversion: A vertical pole with a height of $9.0 \mathrm{~m}$ was erected near the pole of control group. Based on the ground, a probe was placed every $1.5 \mathrm{~m}$ to measure the temperature of thermal inversions from the night to the early morning of the next day. The measurement was used to describe the strength of thermal inversions.

The collecting time of temperature was set to $10 \mathrm{~s}$ all above the three groups. The machine should be turned on at least $1 \mathrm{~h}$ before the frost, and turned off $1 \mathrm{~h}$ after sunrise, so as to achieve a better protective effect ( $\mathrm{Hu}$, et al., 2013; Ribeiro, et al., 2006). Therefore, the machine was set to turn on at 19:00, and then turn off at 7:00 the next day. During the experiment, the change of temperature inside and outside the covered area were recorded in real time. Temperature rise at each measurement point was the average value between 20:00 and 7:00 the next day.

\section{Results and discussion}

\subsection{Influence on airflow}

The average wind speed of background was $0.4 \mathrm{~m} \mathrm{~s}^{-1}$ during the experiment. Maximum airflow velocity, airflowdisturbed duration, and average airflow velocity of each measurement point are given in Table 2. The airflowdisturbed duration is the span of the disturbed airflow that can be detected at measurement points. 
Table 2. Analysis on disturbed airflow

\begin{tabular}{ccccccccc}
\hline & \multicolumn{7}{c}{ Distance of measurement points from machine } \\
Parameters & \multicolumn{7}{c}{$(\mathrm{m})$} & \\
\cline { 2 - 8 } & 5 & 10 & 15 & 20 & 25 & 30 & 35 & 40 \\
\hline $\begin{array}{c}\text { Maximum airflow velocity } \\
\left(\mathrm{m} \mathrm{s}^{-1}\right)\end{array}$ & - & 2.1 & 6.3 & 5.4 & 4.5 & 3.7 & 2.4 & 2.1 \\
$\begin{array}{c}\text { Airflow-disturbed duration } \\
(\mathrm{s})\end{array}$ \\
$\begin{array}{c}\text { Average airflow velocity } \\
\left(\mathrm{m} \mathrm{s}^{-1}\right)\end{array}$
\end{tabular}

The disturbed airflow cannot be detected at $5 \mathrm{~m}$, because it was located in the blind area of frost protection under the machine. Airflow velocity was the largest and airflow-disturbed duration was the longest at $15 \mathrm{~m}$, which has the closest distance from the core position of jet-flow.

With the distance in the range of $15 \sim 40 \mathrm{~m}$, maximum airflow velocity, airflow-disturbed duration, and average airflow velocity all decreased gradually. Where airflow velocity was high, airflow-disturbed duration was also large. Just considering the influence of airflow on canopy, the effective area of frost protection windmachine with continuous oscillation was an annulus formed by circle with radius of $10 \mathrm{~m}$ and $40 \mathrm{~m}$.

Airflow-disturbed duration of measurement points only accounts for about $6.84 \sim 16.84 \%$ of the oscillation period of $190 \mathrm{~s}$. The maximum velocity of airflow at $15 \mathrm{~m}$ reached $6.3 \mathrm{~m} \mathrm{~s}^{-1}$, but it was only a transient velocity. If the wind machine does not oscillate, airflow velocity would be larger, causing a certain damage to the tea leaves, so wind machine with continuous oscillation could effectively reduce frost damage to the crops.

Taking $15 \mathrm{~m}, 25 \mathrm{~m}$ and $35 \mathrm{~m}$ as the instances, the variation of air velocity with time is shown in Figure 2 . It can be seen that airflow velocity rose continuously and reached a high value in $4 \sim 6 \mathrm{~s}$. After that, airflow velocity fluctuated in a certain range, reaching the maximum at $15 \mathrm{~m}$. In the end, the airflow velocity decreased to background level gradually, accompanied by a small range of fluctuations. Therefore, under the action of windmachine with continuous oscillation, airflow velocity at each measurement point presented a trend of rise, fluctuation, and decline.

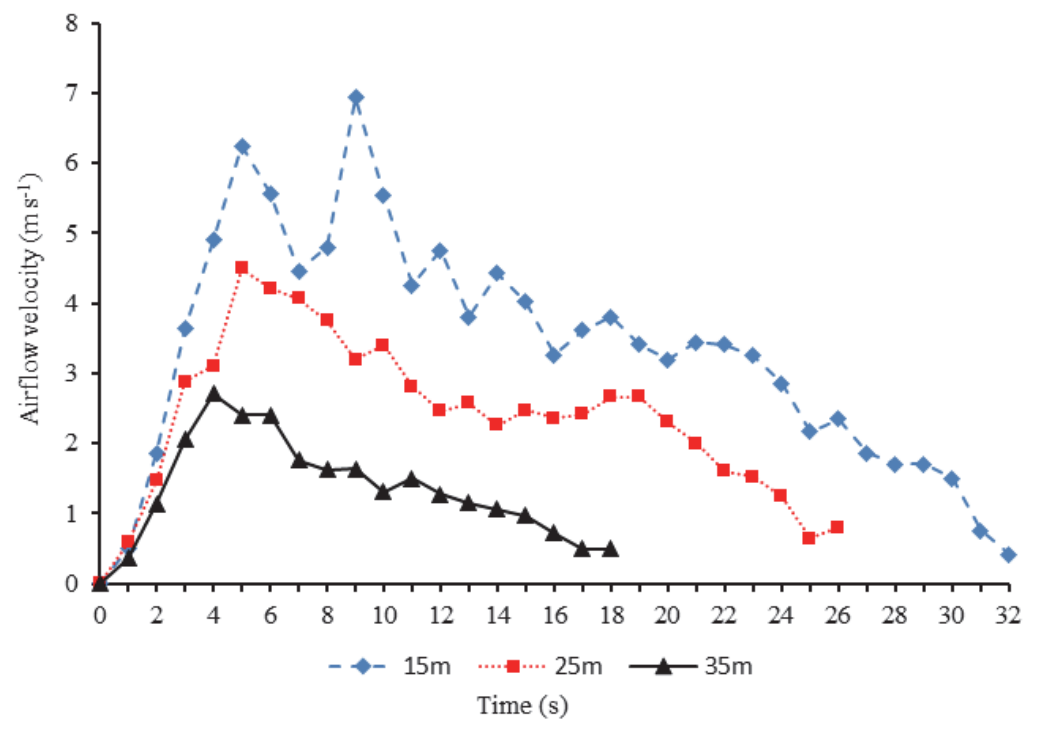

Figure 1. Variation of air velocity

\subsection{Influence on Temperature}

Table 3 shows the average temperature at each height from 19:00 on December 4 to 7:00 on December 5 of thermal inversions. The average reversal intensity between the head of the machine $(9 \mathrm{~m})$ and the top of the tea canopy $(0.85 \mathrm{~m})$ during this period was $3.0^{\circ} \mathrm{C}$. 
Only when the intensity of inversions reaches above $2.0^{\circ} \mathrm{C}$ and the wind speed of background is lower than $2.0 \mathrm{~m}$ $\mathrm{s}^{-1}$ can the frost protection wind machine be turned on to achieve a better effect (Renquist, et al., 1985; Snyder, et al., 2005). The intensity of inversion and the background conditions met these requirements, so frost protection of the experiment was effective.

Table 3. Average temperature at all heights

\begin{tabular}{cccccccc}
\hline Height $(\mathrm{m})$ & 0.85 & 1.5 & 3 & 4.5 & 6 & 7.5 & 9 \\
\hline Temperature $\left({ }^{\circ} \mathrm{C}\right)$ & -3.3 & -2.4 & -1.6 & -1.3 & -0.7 & -0.4 & -0.3 \\
\hline
\end{tabular}

The curves showing the variation of temperature of control group are presented in Figure 2. It can be seen that the temperature has the approximate trend with time at the three heights. However, the average temperature at $85 \mathrm{~cm}$ was $0.5^{\circ} \mathrm{C}$ lower than that at $45 \mathrm{~cm}$, meanwhile the average temperature at $45 \mathrm{~cm}$ was $0.1^{\circ} \mathrm{C}$ lower than that at 5 $\mathrm{cm}$. Therefore, temperature decreased gradually with height, which was the opposite of thermal inversion. However, the inversion disappeared in the daytime. It was because the leaves of the upper canopy were completely exposed to the atmosphere with large influence by the micro meteorological factors such as wind speed, humidity, solar radiation in addition to the atmospheric conditions, while the leaves of the inner canopy were blocked by the upper canopy with less influence by the micro meteorological factors.

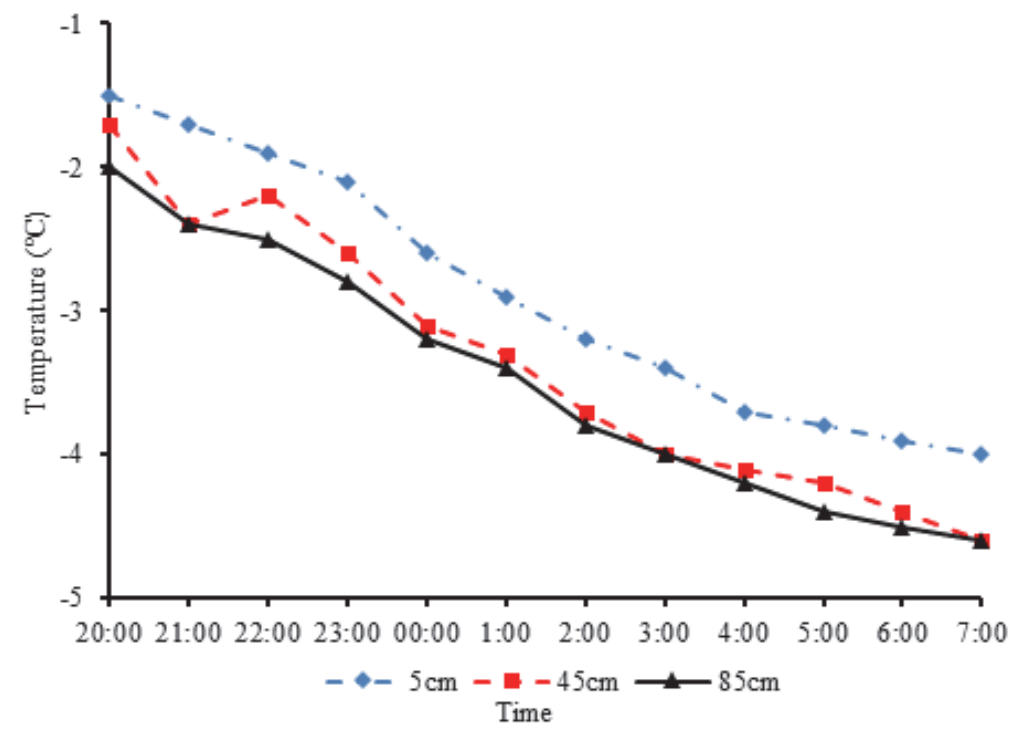

Figure 2. Canopy temperature variation of control group

The temperature rise of frost protection group corresponded to the temperature of different heights of control group. As presented in Table 4, the statistical results show that temperature rise of different measurement points was different, but the measurement points with same distance from the machine and same height from the ground had similar temperature rise in value. Affected by topography, crops and other environmental factors, there were slight differences. Temperature rise decreased with the distance in the range of $20 \sim 40 \mathrm{~m}$ from the machine. However, temperature rise at $10 \mathrm{~m}$ and $20 \mathrm{~m}$ was not consistent with this correlation, because airflow velocity at $15 \mathrm{~m}$ was the largest, which had a greater impact on the range of $10 \sim 20 \mathrm{~m}$. 
Table 4. Average temperature rise of measurement points

\begin{tabular}{|c|c|c|c|c|c|c|c|c|c|c|c|c|}
\hline \multirow{3}{*}{$\begin{array}{l}\text { Distance } \\
\text { from } \\
\text { machine } \\
(\mathrm{m})\end{array}$} & \multicolumn{12}{|c|}{ Temperature rise $\left({ }^{\circ} \mathrm{C}\right)$} \\
\hline & \multicolumn{3}{|c|}{$\begin{array}{c}\text { Group } 1 \\
\text { Height }(\mathrm{cm})\end{array}$} & \multicolumn{3}{|c|}{$\begin{array}{c}\text { Group } 2 \\
\text { Height }(\mathrm{cm})\end{array}$} & \multicolumn{3}{|c|}{$\begin{array}{c}\text { Group } 3 \\
\text { Height (cm) }\end{array}$} & \multicolumn{3}{|c|}{$\begin{array}{c}\text { Group } 4 \\
\text { Height }(\mathrm{cm})\end{array}$} \\
\hline & 5 & 45 & 85 & 5 & 45 & 85 & 5 & 45 & 85 & 5 & 45 & 85 \\
\hline 10 & 2.3 & 2.1 & 2.0 & 1.8 & 1.6 & 1.6 & 2.3 & 2.1 & 1.8 & 1.9 & 1.8 & 1.6 \\
\hline 20 & 1.9 & 1.7 & 1.7 & 2.2 & 2.0 & 1.8 & 2.0 & 1.8 & 1.8 & 2.2 & 1.8 & 1.8 \\
\hline 30 & 1.2 & 0.9 & 0.9 & 1.3 & 1.0 & 0.9 & 1.3 & 1.1 & 1.0 & 1.3 & 1.0 & 0.9 \\
\hline 40 & 0.8 & 0.6 & 0.5 & 0.8 & 0.6 & 0.5 & 0.9 & 0.6 & 0.5 & 0.8 & 0.6 & 0.5 \\
\hline
\end{tabular}

Table 5 presents the average temperature rise at different heights from the ground. It can be seen that temperature rise at $5 \mathrm{~cm}$ was the highest and that at $85 \mathrm{~cm}$ was the lowest for each distance from the machine. The average temperature rise at $45 \mathrm{~cm}$ was $15.9 \%$ lower than that at $5 \mathrm{~cm}$, and the average temperature rise at $85 \mathrm{~cm}$ was $5.7 \%$ lower than that at $45 \mathrm{~cm}$. The results show that temperature rise gradually decreased with height above the ground, which might result from the thermal insulation of canopy.

Table 5. Average temperature rise at different heights

\begin{tabular}{cccc}
\hline \multirow{2}{*}{$\begin{array}{c}\text { Distance from machine } \\
(\mathrm{m})\end{array}$} & \multicolumn{3}{c}{ Average temperature rise $\left({ }^{\circ} \mathrm{C}\right)$} \\
\cline { 2 - 4 } & $5 \mathrm{~cm}$ & $45 \mathrm{~cm}$ & $85 \mathrm{~cm}$ \\
\hline 10 & 2.1 & 1.9 & 1.8 \\
20 & 2.1 & 1.8 & 1.8 \\
30 & 1.3 & 1.0 & 0.9 \\
40 & 0.8 & 0.6 & 0.5 \\
\hline
\end{tabular}

It was found that frost mainly accumulated on the leaves at the top of the canopy, as shown in Figure 3 . The phenomenon was caused by the different temperature rise and its own diversity of temperature with height of the canopy. It can be concluded that disturbed airflow enlarged the temperature difference between the top and the bottom of the canopy. Therefore, in the application of frost protective methods and techniques, the tea leaves at the top of the canopy should be paid attention to especially.

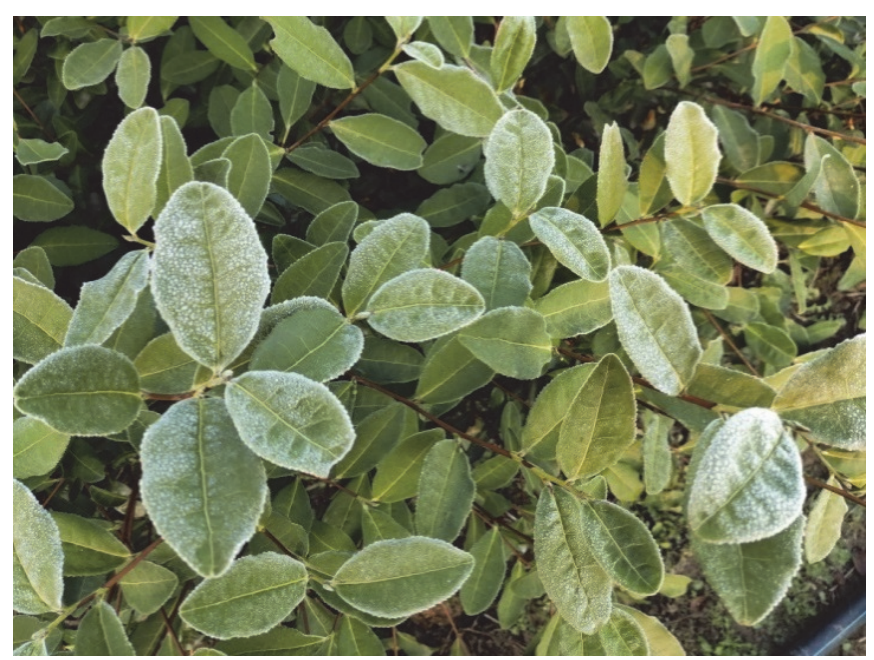

Figure 3. Frost accumulated on leaf surface 


\section{Conclusion}

A frost protection windmachine with continuous oscillation was used in an experiment to understand its influence on microclimate modification in a tea field. Within the distance of $10 \sim 15 \mathrm{~m}$ from the machine, airflow velocity and airflow-disturbed duration rose with the distance and then decreased within the distance of $15 \sim 40 \mathrm{~m}$. For each measurement point, the airflow rose for $4 \sim 6 \mathrm{~s}$, then fluctuated, and finally decreased to the background level. The temperature at the same distance from the machine was close, among which the $10 \mathrm{~m}$ and $20 \mathrm{~m}$ away from the machine increased greatly. Temperature rise decreased with the distance from the machine between 20 and $40 \mathrm{~m}$. Disturbed airflow enlarged the temperature difference between the top and the bottom of the canopy. The wind machine with continuous oscillation had coverage of $48000 \mathrm{~m}^{2}$ and was proved to be effective for tea frost protection.

\section{Acknowledgments}

The authors are grateful for financial support from the Jiangsu Agriculture Science and Technology Innovation Fund (CX(16)1045) and Key R\&D Program of Jiangsu Province (BE2016354).

\section{References}

Battany, M. C. (2012). Vineyard frost protection with upward-blowing wind machines. Agr. Forest Meteorol., 157, 39-48. https://doi.org/10.1016/j.agrformet.2012.01.009

Bey-Marshall, V., Herrera, J., Santibez, F., \& Fichet, T. (2019). Microclimate modification under the effect of stationary and portable wind machines. Agr. Forest Meteorol., 269-270, 351-363. https://doi.org/10.1016/j.agrformet.2019.01.042

Blank, S. C., \& Venner, R. (1995). Evaluating the cost-effectiveness of risk-reducing inputs: wind machines for citrus. Horttechnology, 5(2), 165-170. https://doi.org/10.21273/horttech.5.2.165

Cittadini, E. D., De Ridder, N., Peri, P. L., \& Van Keulen, H. (2006). A method for assessing frost damage risk in sweet cherry orchards of South Patagonia. Agr. Forest Meteorol., 141(2), 235-243. https://doi.org/10.1016/ j.agrformet.2006.10.011

Doesken, N. J., \& Renquist, A. R. (1989). A climatological assessment of the utility of wind machines for freeze protection in mountain valleys. J. Appl. Meteorol. Clim., 28(3), 194-205. https://doi.org/10.1175/15200450(1989)028<0194:ACAOTU>2.0.CO;2

Gambino, V., Gambino, T., \& Fraser, H. W. (2007). Characterization of sound emitted by wind machines used for frost control. Can. Acoust., 35(3), 188-189.

Gu, L., Hanson, P. J., Post, W. M., Kaiser, D. P., Yang, B., Nemani, R. R., Pallardy, S. G. \& Meyers, T. P. (2008). The 2007 Eastern US Spring Freeze: Increased Cold Damage in a Warming World. BioScience, 58(3), 253262. https://doi.org/10.1641/B580311

Heusinkveld, V. W., Van Hooft, J. A., Schilperoort, B., Baas, P., Veldhuis, M. T., \& De Wiel, B. J. (2019). Towards a physics-based understanding of fruit frost protection using wind machines. Agr. Forest Meteorol., 282-283, 1-15. https://doi.org/10.1016/j.agrformet.2019.107868

Hu, Y. G., Wu, W. Y., Melo-Abreu, J. P., Shapland, T. M., Zhang, H., \& Snyder, R. L. (2015). Comparative experiments and effectiveness evaluation on vertical blowing fans (VBF) for frost protection. Int. J. Agr. Biol. Eng., 8(5), 36-42. https://doi.org/10.25165/ijabe.20150805.1419

Hu, Y. G., Zhu X. L., Zhao M. L., Richard, L. S., \& Li, P. P. (2013). Operation effects of wind machines for frost protection of tea trees on different time scales (in Chinese). Trans. Chin. Soc. Agric. Mach., 12, 252-257. https://doi.org/10.6041/j.issn.1000-1298.2013.12.042

Kensuke, K., Daisuke, Y., Kentaro, N., \& Masaharu, K. (2017). Dynamic distribution of thermal effects of an oscillating frost protective fan in a tea field. Biosyst. Eng., 164, 98-109. https://doi.org/10.1016/j.biosystemseng.2017.09.010

Lee, J., Natarajan, B., Eun, W. J., Viswamurthy, S. R., Park, J., Kim, T., \& Shin, S. (2013). Structural and mechanism design of an active trailing-edge flap blade. J. Mech. Sci. Technol., 27(9), 2605-2617. https://doi.org./10.1007/s12206-013-0704-8

Lu, Y. Z, Hu, Y. G, \& Li, P. P. (2017). Consistency of electrical and physiological properties of tea leaves on $\begin{array}{llllll}\text { indicating critical cold temperature. Biosyst. Eng., } & \text { 159, } & \text { 89-96. }\end{array}$ https://doi.org/10.1016/j.biosystemseng.2017.04.012 
Monteith, J., \& Unsworth, M. (2013). Principles of environmental physics: Plants, animals, and the atmosphere (4th ed.). Oxford: Academic Press.

Renquist, A. R. (1985). The extent of fruit bud radiant cooling in relation to freeze protection with fans. Agr. Forest Meteorol., 36(1), 1-6. https://doi.org/10.1016/0168-1923(85)90060-7

Ribeiro, A. C., De Melo-Abreu, J.P., \& Snyder, R. L. (2006). Apple orchard frost protection with wind machine operation. Agr. Forest Meteorol., 141(2), 71-81. https://doi.org/10.1016/j.agrformet.2006.08.019

Snyder, R. L., \& Melo-Abreu, J. P. (2005). Frost protection: Fundamentals, practice and economics-Volume I. Rome: Food and Agriculture Organization of the United Nations.

Vahid, I., Karem, C., Caroline, T., Martin, F., Rainvill, E., \& Hardy, G. (2015). Micrometeorological observations for the evaluation of the selective inverted sink against radiation frost and the potential of a new hybrid system. Procedia Earth Planet. Sci., 15, 920-927. https://doi.org/10.1016/j.proeps.2015.08.147

Wu, W. Y., Hu, Y. G., Yang, S., Mao, K. Q., Zhu, X. Y. \& Li, P. P. (2015). Optimal design of wind machine impeller for frost protection based on CFD and its field test on airflow disturbance. Int. J. Agr. Biol. Eng., 8(5), 43-49. https://doi.org/10.25165/ijabe.20150805.1415

\section{Copyrights}

Copyright for this article is retained by the author(s), with first publication rights granted to the journal.

This is an open-access article distributed under the terms and conditions of the Creative Commons Attribution license (http://creativecommons.org/licenses/by/4.0/). 